aleksandra.chrusciel@lib.uni.lodz.pl

Justyna Rakoczy

justyna.rakoczy@lib.uni.lodz.pl

Biblioteka Uniwersytetu Łódzkiego

\title{
ROLA WYPOŻYCZALNI MIEJSCOWEJ I MIĘDZYBIBLIOTECZNEJ W NOWEJ JAKOŚCI KSZTAŁCENIA AKADEMICKIEGO NA PRZYKŁADZIE BIBLIOTEKI UNIWERSYTETU ŁÓDZKIEGO
}

\begin{abstract}
Academic libraries are a part of university institutions and serve their needs. As those needs change, so do the requirements placed on the library. Evaluating and improving information services to meet user demands is essential to success - fully support the educational goals and the daily teaching and learning activities of the institution. Understanding the information needs and making them available to the appropriate user is very important. Therefore the library departments such as circulation department and interlibrary loan department have come significant changes to adjust to the new users' needs.
\end{abstract}

Słowa kluczowe: wypożyczalnia miejscowa, wypożyczalnia międzybiblioteczna, biblioteka akademicka, usługi biblioteczne, jakość kształcenia.

\section{Wstęp}

Biblioteki akademickie mają dziś różnorodne, złożone i stale zmieniające się potrzeby. Są one w dużej mierze związane z rozwijającą się społecznością akademicką. Zgodnie z komunikatem praskim wypracowanym na spotkaniu europejskich ministrów do spraw szkolnictwa wyższego z dnia 19 maja 2001 r. $^{1}$, uczenie się prze całe życie jest podstawowym elementem europejskiego obszaru szkolnictwa wyższego. To między innymi biblioteki są ważnym ogniwem w budowaniu nowej jakości kształcenia akademickiego. Są bowiem strukturalnie $\mathrm{i}$ organizacyjnie powiązane $\mathrm{z}$ uczelnią. Biorąc udział $\mathrm{w}$ realizacji celów dydaktycznych, dążą do podniesienia skuteczności i efektywności ich działania. Głównym zadaniem bibliotek naukowych uczelni wyższych jest wspieranie procesu nauczania i uczenia się, pomoc w pracach naukowych, przedsięwzięciach badawczych i zawodowych, wymagających specjalistycznego piśmiennictwa oraz odpowiednich narzędzi informacyjnych. Nie ulega wątpliwości, iż podstawowym obszarem funkcjonowania bibliotek pozostaje

${ }^{1}$ Europa. Streszczenia prawodawstwa UE: wszystko, co musisz wiedzieć o unijnym prawie, [dostęp: 20.05.2015], http://europa.eu/legislation_summaries/education_training_youth/lifelong_ learning/c11088_pl.htm. 
bezpośrednia obsługa oraz wsparcie badań naukowych poprzez gromadzenie i udostępnianie zbiorów, zarówno w formie tradycyjnej, jak i elektronicznej, a także baz danych ${ }^{2}$. Ponieważ szkolnictwo wyższe podlega ciągłej transformacji, również tradycyjne funkcje biblioteki i bibliotekarza ulegają zmianie. Biblioteki podejmują nowe zadania, funkcje i jako integralne jednostki uczelni mają realny wpływ na jej rozwój. Istotnym czynnikiem zmian w obszarze edukacji akademickiej są technologie informacyjne. Nowoczesne techniki komputerowe sprawiają, że biblioteki wprowadzają nowe rozwiązania, które mają na celu usprawnienie dostępu do informacji, ułatwienie oraz przyspieszenie realizacji pewnych zadań. Poniżej zaprezentujemy sposób realizacji wspomnianych postulatów na przykładzie dwóch działów, które wchodzą w skład Oddziału Udostępniania Zbiorów Biblioteki Uniwersytetu Łódzkiego: Wypożyczalni Miejscowej (WM) i Wypożyczalni Międzybibliotecznej (WMB) związanych bezpośrednio z obsługą czytelnika - członka społeczności akademickiej uczelni wyższej.

\section{Wypożyczalnia Miejscowa Biblioteki Uniwersytetu Lódzkiego}

Głównym zadaniem Wypożyczalni Miejscowej Biblioteki Uniwersytetu Łódzkiego jest rejestracja użytkowników, wypożyczanie materiałów czytelnikom, ich prolongowanie i przyjmowanie zwrotów. Moduł Udostępnianie systemu SirsiDynix Symphony 3.4 obsługuje rekordy użytkowników, egzemplarzy, wypożyczenia i zwroty oraz realizuje zamówienia i należności względem biblioteki ${ }^{3}$. Czytelnik po aktywowaniu konta w wypożyczalni miejscowej otrzymuje dostęp online do korzystania z szeregu usług bibliotecznych. Może też sprawdzić dostępność interesujących go materiałów i pozycji książkowych. Rolą personelu wypożyczalni wywołanie korzystnego wrażenia u czytelnika i dostarczenie wysokiej jakości usług bibliotecznych. Tu bowiem swe pierwsze kroki kieruje potencjalny użytkownik.

Nowoczesny system umożliwia mu zamawianie książek i czasopism za pomocą dostępnego online konta. Użytkownik logując się na nie $\mathrm{z}$ dowolnego miejsca $\mathrm{z}$ dostępem do Internetu może sprawdzić czy dane zamówienie zostało zrealizowane przez personel biblioteczny. Oszczędza dzięki temu czas, który może spożytkować na dalsze wyszukiwanie i zamawianie niezbędnych materiałów. Może również w każdym momencie anulować listę zamówień z pozycji swojego konta, bez konieczności przychodzenia do wypożyczalni biblioteki uniwersyteckiej. System biblioteczny daje możliwość rezerwowania potrzebnych materiałów, aktualnie wypożyczonych przez innych czytelników. Użytkownik tworzy listę pozycji niezbędnych, a rolą biblioteki jest powiadomienie

\footnotetext{
${ }^{2}$ Organizacja $i$ zarządzanie biblioteka akademicka $w$ kontekście zmian w szkolnictwie wyższym - refleksje ogólne, „Warsztaty Bibliotekarskie” 2007, nr 2-3, [dostęp 15.05.2015], http://www.pedagogiczna.edu.pl/warsztat/2007/2-3/070202.htm.

${ }^{3}$ Udostęnianie. Skrócony podręcznik użytkownika, oprac. T. Masłowska, Poznań 2012, s. 4 .
} 
go o ich dostępności. Ważne ogniwo systemu bibliotecznego stanowią pracownicy Oddziału Udostępniania Zbiorów. Dzięki podaniu personelowi adresu e-mail, podczas aktywowania karty bibliotecznej użytkownik zapewnia sobie mobilny kontakt i dostęp do informacji o stanie konta oraz terminie zwrotu materiałów wypożyczonych. Na pocztę elektroniczną otrzymuje przypomnienie o zbliżającej się dacie zwrotu książek i informację o dostępności zarezerwowanych pozycji. Logując się poprzez katalog komputerowy na swoje konto, ma możliwość prolongaty posiadanych materiałów na okres przypisany do profilu czytelnika, nadanego przez bibliotekarza. Praca z użytkownikiem, przy wykorzystaniu różnych form łączności, jest w znacznym stopniu realizowana na odległość.

Istotną rolą bibliotekarzy Oddziału Udostępniania Zbiorów jest szybkie komunikowanie się z czytelnikami. Biblioteczna praca z użytkownikiem oparta na fizycznej obecności czytelników w bibliotece, ustępuje miejsca komunikowaniu się na odległość, $\mathrm{z}$ wykorzystaniem różnorodnych form łączności ${ }^{4}$. Dzięki systemowi SirsiDynix Symphony 3.4 w module udostępniania personel ma możliwość przesyłania wiadomości bezpośrednio na konto użytkownika. Jest to bardzo pomocne, szczególnie w przypadku odnalezienia ważnych dokumentów czy rzeczy osobistych pozostawionych w gmachu biblioteki uniwersyteckiej. Czytelnicy przy pomocy OPAC odpowiadają na komunikaty oraz sygnalizują swoje potrzeby związane z zapotrzebowaniem na konkretne materiały. To użytkownicy wpływają na formę proponowanych usług bibliotecznych, dlatego tak ważna jest ocena i dostosowanie potrzeb do współczesnego modelu bibliotek.

Również biblioteki wydziałowe biorą udział w realizacji procesu dydaktycznego społeczeństwa akademickiego. Poprzez stopniowe przyłączanie ich do systemu bibliotecznego SirsiDynix Symphony 3.4 ułatwiają czytelnikowi szybsze i sprawniejsze wyszukiwanie materiałów, powiększając jednocześnie zasób znajdujący się w katalogu online. Użytkownik, w zależności od wydziału na którym studiuje, ma możliwość zamawiania książek i czasopism z kilku lokalizacji jednocześnie. Logując się na jedno konto biblioteczne uzyskuje informacje o dostępności zrealizowanych pozycji w każdej z wybranych bibliotek. To bardzo ważne ze względów logistycznych rozwiązanie pozwala zaoszczędzić tak cenny dla czytelników czas.

Misją bibliotek akademickich jest edukacja i kształtowanie kultury informacyjnej. Wychodząc naprzeciw tym potrzebom i oczekiwaniom społeczności akademickiej Uniwersytet Łódzki stworzył projekt realizowany przez Centrum Karier i Współpracy z Pracodawcami pod nazwą Karta Absolwenta, dedykowany absolwentom wszystkich rodzajów studiów. Osoba, która uzyskała dyplom studiów licencjackich, magisterskich, podyplomowych czy doktoranckich na uczelni, za pośrednictwem elektronicznego formularza ma możliwość zamówienia jednego $\mathrm{z}$ trzech proponowanych wzorów karty. Wydawana jest

\footnotetext{
${ }^{4}$ J. Wojciechowski, Praca z użytkownikiem w bibliotece, Warszawa 2000, s. 25.
} 
ona bezpłatnie i bezterminowo, zsynchronizowana z systemem bibliotecznym SirsiDynix Symphony 3.4, po uprzednim aktywowaniu w wypożyczalni miejscowej, uprawnia do korzystania z szeregu usług bibliotecznych.

Praca w Wypożyczalni Miejscowej opiera się głównie na kontakcie z użytkownikiem. Mimo, iż nowoczesny system pozwala ograniczać do niezbędnego minimum częstotliwość jego wizyt w gmachu biblioteki, to właśnie do niej kieruje on swe pierwsze kroki. Tu następuje zazwyczaj jego zetknięcie $\mathrm{z}$ biblioteczną rzeczywistością, ponieważ poznaje zasady korzystania $\mathrm{z}$ bogatego księgozbioru oraz baz danych. To personel WM zaznajamia użytkownika $\mathrm{z}$ funkcjonowaniem elektronicznego systemu bibliotecznego, co ułatwia mu dalsze korzystanie z zasobów. Rzetelna praca, którą wykonuje bibliotekarz oraz umiejętność komunikowania się z czytelnikiem ma duży wpływ na częstotliwość, a także jakość usług proponowanych przez bibliotekę. Dlatego tak ważna jest interakcja bibliotekarz - użytkownikiem. Wprowadzenie ułatwień dla czytelnika oraz częste dostosowywanie rozwiązań systemowych do zmieniających się potrzeb środowiska akademickiego jest elementem przystosowywania się biblioteki do nowej jakości kształcenia.

\section{Wypożyczalnia Międzybiblioteczna Biblioteki Uniwersytetu Lódzkiego}

W tej ciągle ewoluującej i zmieniającej się rzeczywistości akademickiej nowe i bardziej dostosowane do dzisiejszych realiów usługi oferuje również, obok Wypożyczalni Miejscowej, także Wypożyczalnia Międzybiblioteczna.

Agenda ta zajmuje się szeroko pojętym dostarczaniem informacji naukowej, zarówno w formie drukowanej, jaki i elektronicznej, z zasobów różnych bibliotek polskich i zagranicznych oraz z licencjonowanych źródeł elektronicznych. W przypadku udanych transakcji międzybibliotecznych dziesiątki razy dziennie i tysiące razy rocznie dostarczane są w ręce użytkowników niezbędne im źródła informacji. Wszyscy wiemy bowiem, jak niezwykle wartościowa jest informacja $\mathrm{w}$ dzisiejszych czasach, zwłaszcza ta dostarczona na czas. Biblioteki są miejscem, gdzie można ją otrzymać. Jak podaje Jacek Wojciechowski „niezmiennie podstawowa - dawna, obecna i przyszła - rola bibliotek polega na dostarczaniu społeczeństwu treści potrzebnych, a więc wybranych oraz zweryfikowanych, w możliwie licznej i uporządkowanej konfiguracji”, ${ }^{5}$. Niestety nawet największa biblioteka nie jest w stanie posiadać wszystkie niezbędne i poszukiwane przez użytkowników materiały. Niezliczona liczba wydawnictw książkowych i czasopism pojawiających się na rynku oraz coraz to nowe formaty dokumentów dostępnych dla czytelnika są zbyt obszerne. Jednocześnie globalizacja akademickiego i naukowego świata umożliwia odkrywanie przydatnych informacji, które są zlokalizowane w bibliotekach, repozytoriach i archiwach i całego świata. Dlatego niezbędna jest współpraca między

\footnotetext{
${ }^{5}$ J. Wojciechowski, Biblioteki w nowym otoczeniu, Warszawa 2014, s. 53.
} 


\section{4}

bibliotekami, w tym sprawne i skuteczne wypożyczanie zbiorów własnych oraz dostarczanie dokumentów w formie wtórnej. Podkreśla to również Wojciechowski w swojej najnowszej książce pisząc, że ,...przy współdziałaniu zewnętrznym, granic realizacji usług nie wytycza jakakolwiek indywidualna kolekcja zasobów, ani możliwości własne jednej biblioteki, ale stopień zapewnienia dostępu do ofert wielu innych bibliotek"6. Nawet pomimo ogromnych wysiłków digitalizacyjnych Google Books, HaithiTrust i Internet Archive większość dwudziestowiecznych materiałów drukowanych objęta jest prawami autorskimi, co uniemożliwia dostęp online do tych publikacji. Biblioteki pozostają więc najlepszą drogą do uzyskania bezpłatnego dostępu do ogromnej liczby drukowanych materiałów oraz cyfrowych kolekcji, które zazwyczaj obwarowane są niewspółmiernie drogimi opłatami wydawców. Bibliotekarze zaś umożliwiają zarówno dostarczenie, jak i odkrycie nowych zasobów bibliotecznych.

Pomimo wspomnianych zalet wydawać by się mogło, że nie ma obecnie popytu na takie usługi, jak wymiana zasobów własnych z innymi partnerami. Świadczyć może o tym kilka czynników ${ }^{7}$ :

- $\quad$ zwiększona dostępność do materiałów w formie cyfrowej (dokument nie musi być już fizycznie dostępny, można zdobyć go na przykład w Internecie);

- $\quad$ wydawcy oferują dostęp do swoich publikacji przez swoje własne portale;

- $\quad$ coraz większa liczba materiałów dostępna jest za darmo w Internecie;

- $\quad$ społeczność akademicka ma dostęp do szerokich zasobów elektronicznych, zarówno e-booków, jak i artykułów z licencjonowanych czasopism naukowych;

- duża część naukowców wymienia się informacjami samodzielnie, za pośrednictwem różnych portali, mailowo, poprzez fora internetowe czy inne dostępne online formy komunikacji.

$\mathrm{Z}$ drugiej jednak strony czytelnicy oraz sami pracownicy napotykają szereg problemów, z którymi muszą się zmierzyć. Należą tu między innymi:

- ogromna liczba nowych wydawnictw uniemożliwiająca zakup wszystkich nowości;

- coraz droższe umowy licencyjne, zbyt kosztowne, aby umożliwić czytelnikowi dostęp do potrzebnych mu czasopism;

- $\quad$ prawo autorskie, które zabrania umieszczania w sieci książek w postaci cyfrowej;

- embargo wydawców dotyczące dostępu do zawartości najnowszych e-czasopism;

- brak zgody autorów prac doktorskich i habilitacyjnych na dostęp do swoich dzieł;

\footnotetext{
${ }^{6}$ Ibidem, s. 95.

${ }^{7}$ B. Posner, The view from interlibrary loan services. Catalyst for a better research process, "College \& Research Libraries News", 2014, Vol. 75, Issue 7, [dostęp: 24.05.2015], http:// crln.acrl.org/content/75/7/378.full.pdf + html.
} 
- $\quad$ wysokie ceny wydawców za dostęp do pełnych tekstów artykułów z czasopism elektronicznych.

Dlatego tak ważna jest zmiana w sposobie myślenia, nie tylko samych bibliotekarzy, ale też osób odpowiedzialnych za szerzenie kultury. Jak podkreśla Magdalena Wójcik ,nowoczesne biblioteki - nie tylko rozbudowują własną kolekcję, ale również (a może przede wszystkim) zapewniają usługę dostępu do zewnętrznych zasobów"8.

Wypożyczalnia Międzybiblioteczna Biblioteki Uniwersytetu Łódzkiego działa nieprzerwanie od października 1946 r., czyli niemal od początku istnienia biblioteki ${ }^{9}$. Początkowo współpracowała jedynie z dwoma bibliotekami Biblioteką Narodową oraz Biblioteką Jagiellońską. Sytuacja zmieniła się w 1961 r., kiedy to otrzymała własną siedzibę w nowym gmachu biblioteki. Wtedy rozszerzyła swój zakres współpracy również o inne biblioteki krajowe i zagraniczne.

Obecnie WMB zlokalizowana jest w nowym gmachu biblioteki, który został oddany do użytku w październiku 2006 r. Rocznie sprowadza około 600 jednostek różnych materiałów bibliotecznych, w tym książki, artykuły z czasopism, mikrofilmy, niekiedy również czasopisma czy prace doktorskie. Z jej usług korzystają przeważnie pracownicy naukowi poszukujący materiałów do swoich prac doktorskich, habilitacyjnych, ale również do artykułów, różnorodnych prac badawczych, czy też materiałów potrzebnych na zajęcia dydaktyczne. Również studenci piszący prace magisterskie i licencjackie często zgłaszają się z prośbą o sprowadzenie materiałów potrzebnych w toku pracy.

Pomoc w poszukiwaniu i lokalizacji w zbiorach bibliotek krajowych i zagranicznych trudno dostępnych dokumentów, weryfikacji i uzupełnieniu danych bibliograficznych wydawnictw jest kluczową rolą bibliotekarza. Oprócz dostarczania poszukiwanych materiałów swoim czytelnikom WMB zajmuje się także sprowadzaniem materiałów potrzebnych do uzupełnienia zbiorów własnych. Warto jednak zaznaczyć, iż jako jedna z większych bibliotek uniwersyteckich w Polsce, częściej realizuje zamówienia na wypożyczenia ze zbiorów własnych innym bibliotekom w kraju. Wysyłka materiałów realizowana jest w znacznie większej liczbie niż tych sprowadzanych. Stosunek ten jednak zmienia się w ostatnim czasie, co może stanowić dowód na rosnące zainteresowanie usługami Wypożyczalni Międzybibliotecznej. Sytuacja jest zupełnie odwrotna, jeśli chodzi o sprowadzanie i wysyłkę materiałów za granicę. Tutaj większą część stanowią materiały sprowadzane niż wysyłane. Wynika to z faktu, iż biblioteki zagraniczne często są lepiej wyposażone, posiadają większą ilość literatury zarówno naukowej, jak i beletrystycznej w językach obcych, a to właśnie ten typ materiałów jest najczęściej poszukiwany przez użytkowników.

\footnotetext{
${ }^{8}$ M. Wójcik, Web 2.0 w działalności ustugowej instytucji książki, Kraków 2013, s. 35.

${ }^{9}$ Sprawozdanie Biblioteki Uniwersyteckiej $w$ Łodzi za rok akademicki 1946-1947, Łódź 1948, s. 41-43.
} 
Ostatnie lata to czas ciągłych zmian w bibliotekach. Jak zauważa Dorota Grabowska „obecnie biblioteki naukowe nie mogą być tylko miejscami gromadzenia i udostępniania [...] dokumentów piśmienniczych, ale muszą stać się centrami zarządzającymi informacjami z całego świata" ${ }^{10}$. Na skutek dominacji Internetu oraz dzięki rozwojowi nowoczesnych technologii zmienia się stosunek użytkownika do biblioteki. Oczekuje on coraz sprawniejszej i efektywnej obsługi. Konieczne zmiany dotknęły więc niemal wszystkie działy biblioteki, również Wypożyczalnię Międzybiblioteczną.

Pierwszą i zasadniczą zmianą było utworzenie własnego adresu e-mail, co umożliwiło bezpośredni kontakt z użytkownikami indywidualnymi i grupowymi (bibliotekami). Usprawniło to przepływ informacji oraz proces realizacji zamówień poszukiwanych publikacji. Kolejnym ważnym etapem było opracowanie formularzy online tak, aby jeszcze bardziej ułatwić i uprościć proces zamawiania publikacji. Wspólnie z Oddziałem Informacji Naukowej udało się stworzyć formularze online dostępne dla innych bibliotek, zarówno polskich, jak i zagranicznych oraz umożliwić własnym czytelnikom pobranie formularzy zamówień międzybibliotecznych bezpośrednio ze strony internetowej biblioteki bez konieczności wcześniejszego zgłaszania się do Wypożyczalni Międzybibliotecznej.

Jako swoje główne zadania WMB realizuje zamówienia na wypożyczenie krajowe (jeśli zbiorów nie ma w łódzkich bibliotekach), wypożyczenia zagraniczne (jeśli zbiorów nie ma w krajowych bibliotekach), kopie artykułów z czasopism polskich i zagranicznych zarówno z bibliotek krajowych, zagranicznych, jak i poprzez serwisy dostarczania informacji (na przykład Subito ${ }^{11}$ ). Czytelnik, który poszukuje materiałów, zgłasza swoje zamówienie osobiście w wypożyczalni międzybibliotecznej lub miejscowej, bądź pobiera, wspomniany już wcześniej formularz, dostępny online na stronie internetowej biblioteki. Użytkownik znajdzie tam również podstawowe informacje o działalności wypożyczalni, co i na jakich zasadach może zamówić, jaki będzie przybliżony czas oczekiwania na realizację zamówienia oraz informacje, gdzie może skorzystać ze sprowadzonych materiałów. W zakładce Wypożyczalnia Międzybiblioteczna użytkownik odnajdzie również adres mailowy, telefon kontaktowy oraz godziny otwarcia ${ }^{12}$. Formularze dostępne w formacie World i PDF znacznie ułatwiły i przyśpieszyły realizację zamówień czytelników. W dobie Internetu, gdzie wszystko chcemy załatwić online, takie rozwiązanie jak najbardziej spełnia swoją funkcję i cieszy się dużą popularnością.

${ }^{10}$ D. Grabowska, Promowanie ushg bibliotek naukowych PAN przez serwisy $W W W$, [w:] Tradycja i nowoczesność w bibliotece naukowej XXI wieku, red. nauk. A. JanuszkoSzakiel, Kraków 2012, s. 62.

${ }^{11}$ Subito - Dokument Delivery Service, [dostęp 10.05.2015], http://www.subito-doc.de/ index.php?lang=en.

${ }^{12}$ Wypożyczalnia Międzybiblioteczna, [dostęp 26.05.2015], http://www.lib.uni.lodz.pl/? $\mathrm{idx}=\mathrm{udos} \#$ wypm. 
W realizacji zamówień dla klientów wykorzystuje się zasoby Internetu, różnorodne serwisy jak Katalog Rozproszony Bibliotek Polskich [KaRo] czy Katalog Zbiorów Polskich Bibliotek Naukowych [NUKAT], ale też inne katalogi zwarte dostępne online, w tym zagraniczne ${ }^{13}$. Coraz więcej bibliotek udostępnia również katalogi kartkowe w formie zdigitalizowanej. Możliwość przeglądania tych katalogów także przyśpiesza realizację zamówień ponieważ są one kierowane bezpośrednio do instytucji, która posiada poszukiwany tytuł. Zdecydowana większość zamówień przesyłana jest w formie mailowej, co pozwala szybko i sprawnie określić czy zamówienie będzie możliwe do realizacji, a także potwierdzić odbiór lub wysyłkę zamówionych materiałów. Praktyka ta zwiększa bezpieczeństwo materiałów, które są aktualnie w przesyłce oraz pozwala uzyskać i przesłać szybką informację do czytelnika odnośnie do realizacji jego zamówienia.

Porównując zapotrzebowanie na wydawnictwa z poszczególnych dziedzin wiedzy, wypożyczenia międzybiblioteczne odzwierciedlają ogólną tendencję zmian w systemie kształcenia w Polsce. Coraz większą liczba materiałów sprowadzanych stanowią książki obcojęzyczne, głównie w języku angielskim i niemieckim. Wynika to $\mathrm{z}$ faktu, iż zazwyczaj książki te są drogie, a jak wiemy bibliotekom brakuje środków finansowych na zakup nowości zagranicznych. Również fakt, że czytelnicy poszukują książek ze ściśle określonej, często wąskiej dziedziny wiedzy sprawia, że biblioteki naukowe muszą korzystać z życzliwości innych, większych i bogatszych zbiorów bibliotek zagranicznych. W Polsce niestety biblioteki często kupują pojedyncze egzemplarze wydawnictw wartościowych i zwykle udostępniają je tylko na miejscu co uniemożliwia przesyłanie tych pozycji $\mathrm{w}$ ramach wypożyczeń międzybibliotecznych. Nie każdy czytelnik jest natomiast chętny, żeby wybrać się na drugi koniec Polski, aby sprawdzić czy dana lektura będzie przydatna w jego pracy. Dlatego bibliotekarze próbując choć w pewnym stopniu rozwiązać ten problem, przesyłają wzajemnie skany spisów treści, tak aby można było dostarczyć czytelnikowi przydatne rozdziały w formie kserokopii bądź skanów.

Trzeba podkreślić, iż Biblioteka Uniwersytetu Łódzkiego przywiązuje dużą wagę do efektywności realizacji zamówień międzybibliotecznych, na którą składa się sprawność w udzielaniu informacji o zbiorach oraz szybkość dostarczania dokumentów. Ta druga realizowana jest w dużej mierze dzięki przesyłaniu artykułów i fragmentów książek w formie PDF-ów drogą elektroniczną. Skanowanie i elektroniczna transmisja przekazu znajduje bowiem akceptację czytelników, głównie ze względu na wygodę. Ograniczenia wynikające $\mathrm{z}$ prawa autorskiego lub z postanowień licencyjnych czasem niestety utrudniają realizację tej formy usługi.

Kolejną istotną pomocą oferowaną przez WMB jest korzystanie z serwisów elektronicznego dostarczania dokumentów (EDD - electronic document

${ }^{13}$ WorldCat.org: The World's Largest Library Catalog, [dostęp 10.05.2015], https://www. worldcat.org/. 


\section{8}

delivery). Przykładem może być Subito ${ }^{14}$. Jest to serwis online oferujący usługi w zakresie elektronicznego zamawiania i szybkiego dostarczania tekstów artykułów z czasopism znajdujących się $\mathrm{w}$ zbiorach bibliotek niemieckich, austriackich i szwajcarskich. W serwisie dostępne są tysiące czasopism wydawanych na całym świecie. Korzystanie z Subito jest odpłatne. Najczęściej korzystają z serwisu pracownicy naukowi UŁ, potrzebujący dostępu do artykułu, którego nie ma w naszych zasobach elektronicznych czy drukowanych. Kopia artykułu jest dostarczana $\mathrm{w}$ formie pliku PDF do skrzynki e-mail wypożyczalni międzybibliotecznej, a czas oczekiwania nie przekracza 72 godzin. Ponieważ realizacja zamówienia trwa tak krótko, usługa ta zyskuje sobie coraz większe uznanie wśród kadry akademickiej. Jedynym jej mankamentem mogą być dość wysokie jak na polskie warunki ceny za zrealizowanie zlecenia. Koszt sprowadzenia jednego artykułu waha się średnio od 6 do 25 euro. Cena uzależniona jest od opłaty licencyjnej, jaką objęte jest czasopismo, z którego czytelnik zamawia artykuł. Wynosi ona od 3 do 21 euro. Każdorazowo przed zamówieniem czytelnik informowany jest o kosztach sprowadzenia artykułu, aby mógł podjąć decyzje odnośnie realizacji.

Podobnym serwisem dostarczania informacji, z którego WMB korzysta od kilku lat jest GetInfo ${ }^{15}$. Jest to portal prowadzony przez German National Library of Science and Technology - Technische Informationsbibliothek (TIB) - Niemiecką Bibliotekę Narodową, która specjalizuje się w dziedzinie inżynierii, technologii i nauk przyrodniczych. GetInfo oferuje szybkie dostarczanie dokumentów w formie elektronicznej i drukowanej. Opłaty za korzystanie $\mathrm{z}$ serwisu oraz czas oczekiwania na realizację zamówień są podobne jak w przypadku serwisu Subito.

Kolejnym projektem, do którego BUŁ zamierza przystąpić, jest tym razem krajowy produkt - Academica ${ }^{16}$. Jak podaje Biblioteka Narodowa ${ }^{17}$ „Cyfrowa Biblioteka Publikacji Naukowych Academica jest nowatorskim projektem polegającym na utworzeniu cyfrowej bazy książek i czasopism naukowych oraz ich udostępnieniu dzięki wdrożeniu systemu wypożyczeń międzybibliotecznych plików elektronicznych". Ma ona na celu usprawnienie wypożyczeń międzybibliotecznych, a fizyczne egzemplarze (przesyłane między bibliotekami książki) zastąpić przygotowanymi przez Bibliotekę Narodową odpowiednikami cyfrowymi. „W ramach projektu zostało zeskanowanych i udostępnionych badaczom - za pośrednictwem sieci bibliotek naukowych i akademickich - 170 tysięcy najważniejszych publikacji naukowych. Dzięki temu powstało narzędzie umożliwiające szybki dostęp do literatury naukowej, przeznaczone przede wszystkim dla badaczy i studentów"18. Trzeba zaznaczyć,

\footnotetext{
${ }^{14}$ Subito - Dokument Delivery Service, [dostęp 26.05.2015], http://www.subito-doc.de/.

${ }^{15}$ GetInfo, [dostęp 26.05.2015], http://www.tib-hannover.de/en/getinfo/.

${ }^{16}$ Academica, [dostęp 26.05.2015], https://academica.edu.pl/.

${ }^{17}$ Biblioteka Narodowa, [dostęp 30.04.2015], http://www.bn.org.pl/programy-i-uslugi/ cyfrowa-biblioteka-publikacji-naukowych-academica.

${ }^{18}$ Ibidem.
} 
że projekt jest nowatorski i choć niektórzy zarzucają tutaj kopię Polony - biblioteki cyfrowej Biblioteki Narodowej - Academica oferuje użytkownikom znacznie większy zasób, który będzie na bieżąco uzupełniany kolejnymi publikacjami ${ }^{19}$. W czasach, gdy wszystkie światowe biblioteki borykają się z udostępnianiem e-booków oraz innych plików elektronicznych ze względu na restrykcyjne czasem przepisy prawa autorskiego rozwiązanie zaoferowane przez Bibliotekę Narodową jest początkiem zmian na tym polu, również w polskich bibliotekach. Faktem staje się obieg dokumentów w formie elektronicznej, coraz częściej użytkownicy domagają się dostępu do publikacji, których ich macierzysta instytucja nie ma w swoich zasobach. O ile w przypadku artykułów z czasopism $\mathrm{z}$ baz elektronicznych biblioteki radzą sobie w sposób całkiem sprawny, o tyle wypożyczenia międzybiblioteczne e-booków i książek w postaci elektronicznej właściwie w ogóle nie są realizowane. Widzimy więc, że jest jeszcze sporo do zrobienia. Ciągła potrzeba rozwoju sprawia jednak, że jesteśmy w stanie stale unowocześniać ofertę dla swoich klientów, zaś chętne i częste korzystanie z oferowanych przez bibliotekę usług jest najlepszym wynagrodzeniem za podejmowany trud i starania całego środowiska bibliotekarzy.

\section{Zakończenie}

Nie ma wątpliwości, że czasy obecne to dla bibliotek okres przemian i wyzwań. Niosą one ze sobą konieczność uatrakcyjniania i poszerzania oferty biblioteki tak, by placówki te mogły być konkurencyjne na rynku. Biblioteka będąca integralną częścią uniwersytetu odgrywa istotną rolę w pozyskiwaniu nowych rzeszy studentów. Dlatego zapewnienie wysokiej jakości usług staje się dla bibliotek akademickich strategicznym działaniem mającym na celu wykreowanie pozytywnego wizerunku zarówno samej biblioteki, jak i macierzystej instytucji. Współczesne technologie dają bibliotekarzom do dyspozycji metody i nowoczesne narzędzia, które mogą pomóc w promocji instytucji, przyczynić się do sprawnej wymiany informacji i wiedzy między biblioteką a uczelnią, a może nawet do wprowadzenia nowej jakości w procesach nauczania. Usprawnianie i automatyzacja procesów wypożyczania, zarówno miejscowego, jak i międzybibliotecznego, pozytywnie wpasowuje się w najnowsze trendy, które mają bibliotekę uczelnianą uczynić bardziej przyjazną użytkownikowi oraz taką, która będzie potrafiła zaspokoić każdą potrzebę współczesnego czytelnika.

\footnotetext{
${ }^{19}$ Więcej o projekcie Academica w artykule K. Ślaskiej, Academica-mała wielka biblioteka, „Bibliotekarz” 2015, nr 3, s. 4-10.
} 


\section{Bibliografia}

Academica, [dostęp 26.05.2015], https://academica.edu.pl/.

Biblioteka Narodowa, [dostęp 30.04.2015], http://www.bn.org.pl/programy-i-uslugi/cyfrowabiblioteka-publikacji-naukowych-academica.

Europa. Streszczenia prawodawstwa UE: wszystko, co musisz wiedzieć o unijnym prawie, [dostęp 20.05.2015], http://europa.eu/legislation_summaries/education_training_youth/ lifelong_learning/c11088_pl.htm.

Franas-Mirowska U., Organizacja i zarządzanie biblioteka akademicka w kontekśsie zmian w szkolnictwie wyższym - refleksje ogólne, [w:] „Warsztaty Bibliotekarskie”, red. nacz. Wiesława Olczykowska, nr 2-3 [wrzesień 2007], [dostęp 20.05.2015], http://www. pedagogiczna.edu.pl/warsztat/2007/2-3/070202.htm.

GetInfo, [dostęp 26.05.2015], http://www.tib-hannover.de/en/getinfo/.

Grabowska D., Promowanie ustug bibliotek naukowych PAN przez serwisy $W W W$, [w:] Tradycja $i$ nowoczesność $w$ bibliotece naukowej XXI wieku, red. nauk. A. Januszko-Szakiel, Kraków 2012.

Kuś B., Elektroniczne i tradycyjne metody zamawiania i dostarczania dokumentów, „Bibliotekarz" 2003, nr 7/8.

Posner B., The view from interlibrary loan services. Catalyst for a better research process, “College \& Research Libraries News" 2014, vol. 75, issue 7, [dostęp 24.05.2015], http:// crln.acrl.org/content/75/7/378.full.pdf + html.

Subito, [dostęp 26.05.2015], http://www.subito-doc.de/.

Ślaska K., „Academica” jako nowa jakość w systemie wypożyczeń bibliotecznych, „Przegląd Biblioteczny" 2014, r. 82, z. 4.

Ślaska K., Academica - mała wielka biblioteka, „Bibliotekarz” 2015, nr 3.

Udostępnianie. Skrócony podręcznik użytkownika, oprac. T. Masłowska, Poznań 2012.

Wojciechowski J., Biblioteka w komunikacji publicznej, Warszawa 2010.

Wojciechowski J., Biblioteki w nowym otoczeniu, Warszawa 2014.

Wojciechowski J., Praca z użytkownikiem w bibliotece, Warszawa 2000.

Wójcik M., Web 2.0 w działalności usługowej instytucji książki, Kraków 2013.

Wypożyczalnia Międzybiblioteczna, [dostęp 26.05.2015], http://www.lib.uni.lodz.pl/?idx=udos \#wypm. 